\title{
Economy, Industry, Innovation and Technical Democracy ${ }^{1}$
}

\author{
Philippe Defraigne \\ Cullen International ${ }^{2}$ \\ Namur - Belgium \\ phil@cullen-international.com - www.cullen-international.com
}

\begin{abstract}
This paper acknowledges that ethical questions raised by ICT are so fundamental that they include the question of the anthropological changes caused by communications tools. It then looks at the motivation of large companies to discharge their social responsibilities. The paper also argues that Chief Executive Officers (CEOs) are no longer the main decision makers for fundamental strategic corporate choices and that decisions are driven by financial markets. The section on financial markets analyses the reasons for the short-term bias in financial analysts' positions. Finally, a brief look at a specific EU policy (RFID) shows that economic development is at the forefront of the EU agenda and that ethical considerations are seen as mere constraints.
\end{abstract}

Keywords: Capitalism, Financial markets, Innovation, Corporate social responsibility, European Union policy

"International finance has become so interdependent and so interwoven with trade and industry that . . . political and military power can in reality do nothing" Norman Angell - The Great Illusion published in 1913!

1 The views expressed in this paper are those of the author and do not necessarily reflect the positions of Cullen International.

2 Cullen international is a company specialised in the monitoring of the regulation of telecommunications, electronic commerce and media.

Please use the following format when citing this chapter:

Defraigne, P., 2007, in IFIP International Federation for Information Processing, Volume 233, The Information Society: Innovations, Legitimacy, Ethics and Democracy, eds. P. Goujon, Lavelle, S., Duquenoy, P., Kimppa, K., Laurent, V., (Boston: Springer), pp. 89-100. 


\section{Introduction}

In the presentation of the conference, the organisers state that the democratic power is still seeking to regulate the economic system, but it also has to control technological developments in setting up limits defined by societies, and in choosing technical means fitting their ethical ends. While the development of science and technology is largely a self-centred phenomenon, its link with the economy cannot be understated. The Information and Communications Technology (ICT) sector in Europe represents $€ 659 \mathrm{bn}^{3}$ or about $6 \%$ of the European GDP. Therefore, attempts to alter decision making processes in this field should, at the same time, seek to change the functioning of the economy and perhaps even the concept of economic growth.

The conference organisers suggest a better governance of techno-science based on the legitimate meaning of ICT, by favouring institutional education and by avoiding technology policies exclusively based upon risk evaluation or economic interest. This implies quite radical changes in the functioning of democracy.

This paper acknowledges that ethical questions raised by ICT are so fundamental that they include the question of the anthropological changes caused by communications tools. It then looks at the motivation of large companies to discharge their social responsibilities. The article also shows that CEOs are no longer the main decision markets for fundamental strategic corporate choices and that decisions are driven by financial markets. The section on financial markets analyses the reasons for the short-term bias in financial analysts' positions. Finally, a brief look at a specific EU policy (RFID) shows that economic development is at the forefront of the EU agenda and that ethical considerations are seen as mere constraints.

\section{ICT and ethics}

The development of ICT raises many questions. Some are already regulated (privacy), some are openly debated while others are hardly raised. Here are some recent examples.

1. Human rights and the Internet. The behaviour of large Internet companies in China raises a number of ethical issues: Access to the website www.BBCChinese.com has long been blocked by China while the more politically correct (in the eyes of Chinese officials) www.BBCChina.com is accessible. Is the $\mathrm{BBC}$ bowing to Beijing censors? The BBC strongly denies having adapted its website to avoid causing political offence. However, according to the Financial Times, all the Chinese-language China-related news available on the site appears studiously uncontroversial. Furthermore, the site does not have links to the main BBC service! ${ }^{4}$.

Google has decided to censor its new China-based website. In practice, it means that typing the name of a prominent opponent to Beijing such as Liu Xiaobo will generate over half a million links on Google.com and only 19,000 on Google.cn most of them less prominent namesakes ${ }^{5}$. The company defends itself with an

\footnotetext{
3 European IT Observatory - http://www.eito.com

4 Financial Times - February 4, 2006

5 Financial Times - February 15, 2006
} 
utilitarian argument: Chinese users are better off with a censored Google than with no Google at all. At least, Google has a policy of letting users know when results have been censored - a policy not followed by local competitors such as giant Baidu. Chinese users appear to be split on Google policy. Some support it while others quote a Chinese proverb: "Do not do unto others what you would not have them do unto you". Utilitarianism versus Kantian ethics. To Google's credit, the company is not offering its blogging or communications services in China, out of concern for the privacy of potential users.

Yahoo has accepted to provide traffic data information to the Chinese authorities. This has led to the prosecution and jailing of journalists ${ }^{6}$.

These anecdotes raise one more fundamental question: how great a violation of human rights would it take for the Internet companies to decide that they could no longer remain in China?

2. Internet governance. The management of the Internet, in particular a number of top level domain names by ICANN on behalf of the US Department of Commerce has caused discomfort around the world, at least among governments. During the negotiations that led to the UN World Summit on Information Society (WSIS) in Tunisia in November 2005, Europe's support for a proposal to give a greater role to governments has met with fury from the Internet community and telecom industry and with undiluted enthusiasm from the autocratic states! Viviane Reding, European Information Society and Media commissioner, justified the European position by saying that if a multilateral approach cannot be agreed, countries such as China, Russia, Brazil and some Arab states could start operating their own versions of the internet and the ubiquity that has made it such a success will disappear.

3. Closed Circuit Television. A recent estimate puts the number of CCTV cameras in the UK at $4 \mathrm{~m}$ - one for every 14 people. If you live in London, you are likely to be on camera 300 times a day. The policy is about to start using a new system that will automatically link an estimated 3,000 CCTV cameras across the country with car registration records and other data. Here again, reality has surpassed science fiction.

\section{ICT and Anthropological changes}

American novelist William Gibson is usually credited for coining the expression cyberspace. The concept of anybody being potentially connected with anybody anytime anywhere brings radical changes in the our perception of space (death of distance) and time. The head of the famous MIT's Media Labs, William Mitchell ${ }^{7}$ argues that with the advent of mobile devices and wireless Internet access, digital bits no longer exist in a separate sphere called cyberspace but have gone on location in the real world. The trial separation of bits and atoms is now over, Mitchell argues. The result is the rise of a human cyborg: a biological core surrounded by extended, constructed systems of boundaries and networks. In this new world, the social ties that exist are no longer provided by a continuous home turf; increasingly, my sense 
of continuity and belonging derives from being electronically networked to the widely scattered people and places I care about.

In Barcelona, a night club, the Baja Beach Club, uses electronic implants to identify its VIP clients. The rice grain-sized VeriChip RFID device implanted in their hand or arm is also used to pay for drinks with a wave of the hand. The Mexico police department has had over 170 members of its force implanted with the Verichip. This allows them to access databases and, in rare instances, track an officer in case of a kidnapping

Increasingly, everyday talk illustrates Mr Mitchell's theories: I can't talk to you anymore, I don't have any batteries left. Clearly, the network of our contacts is mediated by electronic address books - in SIM cards, mail browsers and buddy lists. We need urgently to decipher what this proliferation of new technologies will have on our relationships and on our brains. Why remember things when you have Google? How will it affect our sexual psyche?

Research ${ }^{8}$ carried out by Glenn Wilson, Institute of Psychiatry at the University of London, compared two groups: one working in a quiet environment and another subject to a barrage of calls and email. The effective IQs of the members of the second group were reduced by 10 points. For comparison, for regular cannabis users the drop is around four points! The impairment only lasts for as long as the distraction. But you have to ask whether our current obsession with constant communication is causing long-term damage to concentration and mental ability, says Dr Glenn Wilson.

\section{Corporate Social Responsibility (CSR)}

1. CSR is good for profits. Among the responses to calls for a more ethical approach to business, corporations have developed the concept of corporate social responsibility (CSR). Hank McKinnell, chairman and CEO, Pfizer, and Chairman of the Business Roundtable explains that CEOs are increasingly committed to socially responsible corporate behaviour because it is essential to profitability: "If we're seen by the community as providing goods and services that enable people to live a happy, long life, society will want us to succeed. If they see what we're doing in education and sports programs, that's important. Otherwise, society will hope that we fail. If we continue to be disrespected by the public, it makes us a target. People will say "regulate them". Excessive regulation is certainly one of the costs"."

2. CSR and regulation. While Mr McKinnell's case appears to be compelling there are instances where companies take action only when they are on the verge of being regulated. In the US, Coca-Cola, PepsiCo and Cadbury Schweppes have decided to remove sugary beverages from school vending machines ${ }^{10}$. However, the decision was only taken under threat of regulation and law suits. In 2005 Arnold Schwarzenegger had banned soft-drink vending machines from California's state schools. Furthermore, a number of Republicans have dropped their opposition to regulation in the light of growing evidence that obesity is harming productivity and contributing to rising health costs. $17 \%$ of US children are clinically obese (up from

8 Guide to avoiding info-mania - published by Hewlett-Packard - April 2005

9 New-York Times - April 29, 2006

10 Financial Times May 5, 2006 
$14 \%$ in 1999)! Cases like this have created some doubts in the public about the true commitment of at least some businesses to their social responsibilities.

3. A useful typology. Like Mr McKinnell, David Varney, Chairman, mmO2 plc (European mobile phone group) and Chairman, Business in the Community, strongly believes that CSR makes good business sense: "Why are we doing these things (CSR)? Is it because we're interested in profits? Yes, absolutely. It's our job to make profits. We'd be out of a job if we didn't. We behave responsibly to protect our corporate reputation. If we had a lousy reputation, we wouldn't get customers. But society should share in the profits of our success. CSR is win-win. It's good for us. It's good for the community. It makes employees feel motivated about what they're doing. It makes customers feel good about what they're buying. It makes good business sense."

Mr Varney provides a useful typology of criticisms against $\mathrm{CSR}^{11}$

a) Free-market view. The conservative, free-market view sees corporate philanthropy essentially as stealing from shareholders. As the Nobel Prize-winning economist Milton Friedman once famously said, the responsibility of corporate executives is to stay within the law and to make as much money for their investors as possible. Anything else is harmful to the owners of the business. Mr Varney dismisses the free-market approach as a short-sighted critique. Shareholders are interested in sustainable profitability. In today's marketplace, companies need to be resilient. They need to be socially responsible to survive. Whatever CSR takes out, it puts back in - in long-term value. A company cannot survive and thrive if it does not look beyond the bottom line. Companies need strong brands and sterling reputations. They need a satisfied workforce. Any shareholder who's interested in sustainable profitability is interested in all the benefits that CSR can bring.

b) The leftist view. The second criticism comes from the left end of the political spectrum. These critics say CSR is a good thing, but it's not working as well as it should. We therefore need to strengthen it with regulation. State intervention will fix it. Mr Varney unsurprisingly takes the view that a successful approach to social responsibility cannot be achieved with a regulatory cookie cutter. It has to be indigenous to the culture of the company. Each industry - and each environment calls for a different approach. The case for regulatory mechanisms to achieve social responsibility is wrongheaded and pernicious. A one-size-fits-all regulatory system will do far more harm than good.

c) CSR is hypocritical. The final criticism is that CSR is hypocritical, a smokescreen to hide the truth - mere window dressing on a system that is ruthlessly self-serving. The classical example is the company that claims to be socially responsible - while making people redundant. Mr Varney's answer is that the capitalist marketplace allows for the ebb and flow of competing interests. In a system such as ours, companies sometimes have to adjust their workforce to survive. That's an inevitable outcome of a dynamic marketplace. That's its strength. When companies downsize to survive, the system produces other opportunities.

4. The compelling imperative to generate short-term profit. Recent developments at Citigroup, the largest bank and the fourth largest company by market capitalisation in the world, illustrate the difficulty to instil an ethical 
culture $^{12}$. When Chuck Prince took over as the new CEO at Citigroup in 2003, the bank's reputation had been tarnished by its involvement in various financial scandals including Enron, WorldCom and Parmalat. The costs of settling the resulting law suits ran into several billions. Prince sought to address the problem by asking 300,000 employees in 100 countries to adhere to a new code of conduct ${ }^{13}$. The code was based on three pillars: a company with the highest standards of ethical conduct; an organisation people can trust; a company dedicated to community service.

Huge efforts were made to embed the code through training programmes and ethics courses.

In July 2004, Citigroup's London operations became involved in what became known as the Dr Evil trade. In short, on a quiet day of August 2006, bond traders placed in 18 seconds a volume of sell orders equivalent to a normal day of trading on the Italian electronic bond market. It bought back the bonds the same morning, earning a profit of $€ 18.2 \mathrm{~m}$. The trick had a number of negative effects on other banks, on the Italian electronic bond market (MTS) and worse for Citigroup, on European governments who started to worry about a rise in the cost of servicing their debt. This is difficult to reconcile with the bank's code that states: "we treat our customers, suppliers and competitors fairly". Irrespective of any ethical considerations, angry European governments withdrew business from Citigroup. Several financial authorities opened enquiries and imposed fines (e.g. $£ 14 \mathrm{~m}$ by UK FSA) on Citigroup. The top management recognised the bank had breached its own ethical standards. The traders involved were briefly suspended but nobody was fired! This raises the question of which values Citigroup really stands by.

The recent events at Citigroup show that tensions between the seemingly overwhelming need to generate short term financial results and compliance with company ethical policies are so intense that it can lead a company to actually behave in a manner that is detrimental to its own long term prosperity.

The following section looks at this short-termism of the functioning of today's financial markets.

What's wrong with today's market economy? Our time is characterised by the fall of all the ideologies that shaped politics and society in the previous century. In the Western world, communism and religion are being replaced by idols such as economy and science that are filling in the vacuum. This paradigm shift has many consequences including the self centred progress of science and technology - no longer a means to an end but a goal in itself - and the development of empty consumerism. This section will seek to shed some light on another aspect of today's economy: the short term effects of financial capitalism.

a) Fund managers short-term view. Ten to twelve million individuals control half the market capitalisation worldwide ${ }^{14}$. According to Cap Gemini - Merrill Lynch's 2006 survey $^{15}$ of the "high net worth individuals", $8.7 \mathrm{~m}$ have more than $€ 1 \mathrm{~m}$ to invest in financial assets. While in the past individuals invested in companies through financial intermediaries such as banks, the share of the latter has shrunk

12 The day Dr Evil wounded a financial giant - Financial Times August 232006 13 www.citigroup.com/citigroup/ corporategovernance/data/codeconduct_en.pdf 14 Le Capitalisme Total by Jean Peyrelevade - Seuil $15 \mathrm{http}: / / \mathrm{www} . u s . c a p g e m i n i . c o m /$ worldwealthreport06/ 
dramatically. Increasingly, investors allocate their capital directly to firms through the stock market. This is known as financial disintermediation. It does not mean that individuals trade their shares in companies themselves, but that pension funds and insurance companies simply manage their clients funds for a fee and pass on the gains and losses. They are not real intermediates as bankers used to be. In past centuries, the power inside a company was in the hands of the management. Today, approximately half of the stocks are held by fund managers subject to intense competition, stringent regulation and a duty to look after the fund they manage. In this new world, the United States hold half of the financial assets worldwide. Europe controls $30 \%$ including $10 \%$ for the UK alone. When looking at pension funds alone, US domination is even stronger: two thirds are North American and less than $15 \%$ European (11\% for the UK alone). This is the direct consequence of European countries choice to fund pensions on a pay-as-you-go basis rather than through the accumulation of financial assets. The indirect consequence is that financial markets are dominated by US fund managers. For example, Calpers, the pension fund for California civil servants, manages assets worth more that $\$ 150 \mathrm{bn}$. These funds buy all the stocks constituting stock indices such as the Dow Jones and then, under the corporate governance banner, weigh heavily on the management of those companies (a practice known as shareholder activism). A recent story published in the Financial Times $^{16}$ illustrates the environment in which fund managers are working. In Ireland, fund managers investing Ireland's E15bn National Pension Reserve Fund (NPRF) have been told their 2005 performance was lacklustre and warned their mandates are under review. The NRPF explained that "while their equity performance in 2005 was in line with its benchmark, our objective was to outperform". Instead, it underperformed the index of Irish pension funds, which achieved $21.2 \%$ return against the NPRF's $19.6 \%$. According to the FT, the pressure by NPRF on its fund managers is continuing evidence that short-term criteria are applied to portfolios, even those with very long-term investment horizons - the NPRF will not distribute any of its assets to pensioners before 2025! The FT notes that although the NPRF is wary of openly criticizing its fund managers, Paul Carty, chairman of the commission appointed by the government to oversee the fund, remarked that "some active managers have outperformed". This was taken as a big hint that some managers had not. "They know who they are" said an official at the National Treasury Management Agency, the government agency that runs the fund. Needless to say that pension funds could adopt a more ethical attitude. The Norwegian government pension fund, the fourth largest in the world ( $\$ 236 \mathrm{bn})$, provides a good example. In June 2006 , it divested $\$ 436 \mathrm{~m}$ worth of shares from Wal-Mart for "serious and systematic" labour violations in several countries". The Norwegian fund includes holdings in $\mathbf{3 5 0 0}$ foreign companies and these are being scrutinised for possible human rights and environmental abuses. Stakes have already been sold off in companies involved in nuclear weapons (Boeing) and land mines. 
b) CEOs' rapid turnover. According to a Booz Allen Hamilton (BAH) 2004 study ${ }^{18}$ of the world's 2500 largest companies. In 2004, underperforming CEOs were removed after 4.5 years (world average). In BAH's judgment, this is an appropriate period. A 15-year vision is irrelevant and research shows CEOs need 3 to 5 years to develop their strategies and see them through to their results. CEOs on a short leash tend to become more risk averse and may be reluctant to embark on riskier projects, such as big investments or mergers and acquisitions activity. In Europe in particular, the pendulum may already have swung too far toward the short term. In 2004, CEOs removed for poor performance were in office for a median tenure of two and a half years, " an astonishingly and counterproductively brief period of time ". Many of the fundamental changes needed to make companies competitive require more than two years to take effect, especially given the region's tradition of cooperative labour relations and the high social costs associated with transformative change. Europe may be entering a cycle in which transformative change is required.

c) Single-minded financial markets. Another characteristics of financial markets is their tendency to be single-minded. As shown above, this can probably be explained by the fact that the relative performance of a fund manager vis-à-vis others is more important than the absolute return he generates. This can sometimes lead large companies to take absurd decisions like the famous European $3 \mathrm{G}$ auctions (see table below). The proceeds of the UK auction brought the government 5 to $6 \%$ of its 2000 budget!

\begin{tabular}{|l|l|l|l|}
\hline Country & End of the auction & $\begin{array}{l}\text { Total bids/ } \\
\text { licence fees in } € \text { bn } \\
\text { capita } \\
\text { in } €\end{array}$ \\
\hline UK & April 2000 & 36 & 620 \\
\hline Netherlands & July 24, 2000 & 2.7 & 181 \\
\hline Germany & August 2000 & 50.8 & 618 \\
\hline Italy & October 2000 & 12 & 208 \\
\hline
\end{tabular}

Table 1 : Largest European $3 G$ auction bids

In that particular instance, it is important to realise that the top management of the mobile operators that committed theses large amounts had no choice but to obtain a $3 \mathrm{G}$ licence (or resign). During 1999, there was a string of studies produced by top investment banks and reputable consultancies explaining the importance of $3 \mathrm{G}$. The message from financial analysts to mobile operators was clear, if you don't get a $3 \mathrm{G}$ licence you have no future. In the year that followed the auction, the CEOs of most of the companies involved in the auction were removed - the wind had changed. What this episode demonstrates is the relative lack of freedom of seemingly powerful CEOs vis-à-vis financial markets.

18 CEO succession 2004 - The world's most prominent temp workers - in Booz Allen Hamilton strategy + business issue 39 
d) Where is the crime? So to sum up, fund managers are summoned to produce short term results and CEOs that do not deliver quickly are swiftly replaced. For Jean Peyrelevade $^{19}$, the former CEO of several French financial institutions such as Crédit Lyonnais, the strength of present-day capitalism arises from the nature of the shareholders and the functioning of the fund management sector. On the one hand, shareholders are widely dispersed, have a single aim (get richer) and are anonymous because of their (large) number and the ordinariness of their conditions. These characteristics confer on them a kind of democratic legitimacy. On the other hand, the fund management industry cannot be considered as liable as it is merely serving the interest of its clients. Where is the crime if nobody is guilty?

\section{EU policy in the ICT sector: the case of Radio Frequency Identification (RFID)}

\subsection{EU policy objectives}

The Commission policy in the electronic communications sector is pursuing the two main objectives:

- promote ICT developments as a growth engine;

- increase consumer welfare by encouraging the development of a broader variety of services and lower prices. This is mainly achieved by policies promoting competition but also in some cases by policies aimed at reducing the "digital divide" i.e. the gap between those who have access to and are able to use the Internet and those who don't.

These two objectives have been at the centre of EU policies for two decades and continue to guide the EU agenda on new topics such as Radio Frequency Identification (RFID) (see B. below).

a) ICT as a growth engine. ICT industries are one of the main drivers of economic growth. Their impact on the improved efficiency of other sectors has multiplier effects far greater than the size of the industry itself. Given the rapid expansion of wireless communications, radio spectrum is a key aspect of increasing importance for the functioning the ICT industry. Today, spectrum-dependent industries are estimated to represent between 2\% to 3\% of Europe's GDP, and ICT industries as a whole play a major role in Europe's effort to achieve the Lisbon goals. They are responsible for $40 \%$ of growth and $20 \%$ of investment in R\&D.

b) Consumer benefits. Spectrum can also help in bridging the digital divide. In many Member States, particularly those that joined the European Union in 2004, mobile penetration is much higher than that of fixed telephony, providing connectivity much faster than would have been possible through a fixed telephone. But we need spectrum coordination if we want to go on with mobile penetration. 


\subsection{Technology assessment is not on the forefront of $E U$ policy}

a) What is RFID? A Radio Frequency Identification Device (RFID) consist of a microprocessor connected to an antenna for the communication of an identifying code. RFIDs are used on certain goods as tags, to track products along the supply chain, and for many other applications such as ski passes, security, and other sensor devices. The Commission does not see RFID as an end in itself but as the forerunner of many increasingly "intelligent" objects that interact with each other and "help humans in ever more sophisticated ways. RFIDs are the precursors of a world in which billions of networked objects and sensors will report their location, identity, and history".

b) RFID is good for the economy. According to the Commission the RFID market is expected to grow fast over the next ten years. Cumulative sales of RFID tags so far amount to 2.4 billion, with 600 million tags being sold in 2005 alone! The number of tags delivered in 2016 could be over 450 times the number delivered in 2006. The deployment of RFID technology is expected to make a major contribution to growth and jobs. According to the Commission, RFID will significantly improve product quality, reduce fixed asset costs and stocks by $5 \%$, improve sales by $3 \%$, reduce labour costs in physical product movement by $65 \%$, and generate a $45 \%$ annual growth for RFID technology and application providers. Furthermore, RFID implementations are expected to become a source of new business models and a creator of quality high-tech jobs.

c) How the Commission sees its role. The Commission believes it is necessary to build a cross-society consensus on technical, legal and ethical issues associated with RFID and to intervene, where required, with regulatory instruments. The issues which need to be addressed include privacy, radio spectrum allocation and the interoperability of systems, not least across EU borders.

\section{Social consensus}

The Commission sees that to exploit "the economic potential of RFID, privacy and consumer concerns associated with the use of RFID tags need to be handled constructively, with the assent of all stakeholders".

\section{Privacy}

RFID is generating a number of important questions including how to ensure that RFID tags are not abused to invade the privacy of consumers and the need to destroy RFID tags, when they could be useful for self-configuring products or automating warranty checks. The EU policy on RFID is in line with its policy in other ICT sectors. The growth of the economy is the objective while societal aspects are seen as constraints to be handled tactfully to ensure the success of the economic project. 


\section{Conclusion}

In the presentation of the conference, the organisers state that the legitimacy of technological innovations requires a connection between the technical justifications and the social ones, to consider their ethical meanings and to demonstrate their democratic opportunity.

One prerequisite for a better connection between technical and social justifications is a reform of financial markets and a more responsible attitude by governments to the management of public pension funds. The Norwegian government is showing the way in this respect. Without such a change, CEOs will not recover a sufficient degree of freedom to pursue ethical goals.

Although it frequently presents itself as besieged, the market economy model has no rival as other models failed! The imperative need to rethink the development of society is made more difficult by the absence of alternatives. Jean Peyrelevade ${ }^{20}$ notes that the intellectual debate on the functioning of the world economy is fragmented. The dialogue between Chinese, German, Russian, American... intellectuals is not easy. No global forum exists where a public debate could take place on the foundations of the new order that rules the planet - some would argue that Davos fulfils this role. The complexity of globalisation weakens the possibility of having such a dialogue while the simplicity of profit maximising prevails. Ethical values are closely linked to the history and culture of people. By inclination intellectuals prefer to focus on national matters where they can build bridges with the past and gain the recognition of their peers rather than concern themselves with the barbarian immediacy of financial markets.

Finally, a better connection between technical and social justifications can only be achieved by raising the awareness of the public. In the 80 s and early 90 s, actions by academics and civil liberties organisations have successfully convinced the public of the potential danger of ICT on privacy. This in turn led governments to take the necessary legislative measures and businesses to amend their codes of conduct. 